\title{
Oriainal Article
}

\section{Comparison of Parenting Style in Single Child and Multiple Children Families}

\author{
Masoumeh Alidosti $^{1} \quad$ Seyedeh Leila Dehghani $^{1} \quad$ Akbar Babaei-Heydarabadi $^{2} \quad$ *Elahe Tavassoli ${ }^{3}$
}

1- Department of Public Health, Behbahan Faculty of Medical Sciences, Behbahan, Iran

2- Department of Public Health, School of Health, Ahvaz Jundishapur University of Medical Sciences, Ahvaz, Iran

3- Department of Public Health, School of Health, Shahrekord University of Medical Sciences, Shahrekord, Iran

*tavassoli.eb@gmail.com

(Received: 26 Oct 2015; Revised: 27 Apr 2016; Accepted: 20 May 2016)

\section{Abstract}

Background and Purpose: Family is the first and the most important structure in human civilization in which social lifestyles, mutual understanding, and compatibility is learned. Studies have shown that parenting style, is one the most important and fundamental factors in personality development. The purpose of this study was comparison of parenting style in single child and multiple children families.

Materials and Methods: This study, in total, 152 mothers from Andimeshk city, Iran, were selected by random sampling. Data were collected from a health-care center was chosen randomly, mothers who had 5-7 years old children were enrolled in this study. The data collecting tool was the questionnaire which investigates permissive, authoritative, and authoritarian parenting styles in parents. After data entry in SPSS software, the collected data were analyzed by ANOVA, independent t-test, and Pearson correlation test.

Results: The mean age of the participants was $32.71 \pm 5.39$ years old participated in this study. 69 mothers (45.4\%) had one child, 53 (34.9\%) had 2 children, and 30 mothers (19.7\%) had 3 and more children. The mean score of permissive parenting style was $19.97 \pm 5.13$ in single child families; the mean score of authoritative $(19.56 \pm 4.70)$ and authoritarian parenting style $(34.50 \pm 2.81)$ that difference was significantly $(\mathrm{P}<0.050)$.

Conclusion: According to the results of this study, it seems that having more children would make parents more logical and paves the way for upbringing children. Therefore, it is recommended to plan some educational programs about this issue for parents.

[Alidosti II, Dehghani SL, Babaei-Heydarabadi A, *Tavassoli E. Comparison of Parenting Style in Single Child and Multiple Children Families. Iran J Health Sci 2016; 4(2): 49-54] http://jhs.mazums.ac.ir

Keywords: Child Rearing, Parenting Style, Children 


\section{Introduction}

Family is the first and the most important structure in human civilization in which social lifestyles, mutual understanding, and compatibility is learned. Family is the best context for flourishing human capabilities and talents (1) and it has a basic role in people's personality formation. Human starts his living from family and the base of his personality and intellectual values establish there (2). Each family utilizes specific methods for the personal and social education of their children. These methods, that are called "parenting style," are affected by various factors such as biological, cultural, social, political, and economic factors (3). Studies have shown that among various contributing factors of personality development, parenting style is one the most important and fundamental ones (4). Parenting is a complicated activity that includes some special methods and behaviors that affect children's growth separately or with interaction with each other. Actually, the base of parenting style is parents' effort to control and socialize their children (5). Parents try to transfer the norms and values of their own society which has been imposed to them by their own parents and teachers (4). The perception of parents about their children is also affected by their economic, social, and cultural levels or cultural capital (6). We can defiantly say that the family environment and parenting styles have important impacts on children's psychosocial development (6). Researchers believe that there is a significant association between parenting styles and anxiety in children and adolescents (7). The method that parents adopt to bring up their children has a fundamental role in their children's mental health (8) and some studies have shown that opposition defiant disorder and conduct disorder and also problems in nurturing children are associated with the number of children in the family (9). In Farnoodian et al. study (10), there is the difference between parenting style and perfectionism and self-regulation in single child and multiple children families. In recent decades, the reduction in childbearing in Iran has been in a way that the $50 \%$ decrease in fertility, not only has made Iran unique among Islamic countries but such a record has not been observed anywhere else (11). Considering the importance of childbearing and parenting from Islamic, sociology and psychology perspective, it seems that comparison of the parenting styles in single child and multiple children families may provide useful information about the impact of the number of children on the method of parenting, and the result may be used in parenting and childbearing educations. Therefore, this study is conducted to compare the parenting styles in single child and multiple children families in Andimeshk city, Iran in 2015.

\section{Materials and Methods}

This is a cross-sectional descriptive study conducted in Andimeshk city in 2015. Among 5 health-care centers of Andimeshk city, one center was chosen randomly. The statistical population was 208 mothers with 5-7 years old children who had a profile in the health-care center. The sampling was done according to the census information. At first, a list of eligible people was prepared. Then by telephone calls, the aim 
of the study was explained to them and those who desired to participate in the study were asked to come to the health-care center and fill the questionnaire. Consent was required to participate in the study and participants were assured that their information would be kept confidential.

The data were collected by Bamerind parenting style questionnaire. This questionnaire in adopted from the theory of parental authority. This theory that was created by Diana Baumrind contains three prototypes of parenting style which are permissive, authoritarian, and authoritative. This questionnaire includes 30 statements that 10 of them are related to permissive, 10 to authoritative, and 10 to authoritarian prototype. Reliability of 3 subscales has been reported to be $0.81,0.86$, and 0.88 , respectively (12). This questionnaire has been used in several studies in Iran and it has been reported to be valid and reliable (13-15).

Questions were in Likert 5 choice scale (from completely agree to completely disagree) and scores were ranged from 0 to 4 . By summing the scores, 3 discrete scores for permissive, authoritative, and authoritarian parenting style were obtained. The analysis of collected data was done by SPSS software (version 16; SPSS Inc.,
Chicago, IL, USA) and using statistical tests of ANOVA, independent t-test, and Pearson correlation coefficient. The significance level was set at 0.050 .

\section{Results}

In this study, 152 mothers participated. The mean age of mothers and their last child was $32.71 \pm 5.39$ and $6.06 \pm 0.76$ years old, respectively. 13 participants $(74.3 \%)$ were housewives and $39(25.7 \%)$ were employed. The education level of 28 people (18.4\%) was under diploma, 57 people $(37.5 \%)$ diploma, and 67 people (44.1\%) academic. 69 people of participants $(45.4 \%)$ had one child, $53(34.9 \%)$ had 2 children, and 30 people $(19.7 \%)$ had 3 and more children. The comparison of mean scores of parenting styles (permissive, authoritative, and authoritarian) in families with 1 child, families with 2 children, and families with 3 and more children. ANOVA test showed that there was a significant association between number of children (Table 1) and parenting styles, Tukey's post-hoc test showed the mean score of permissive style in single child families was significantly more than families that have 2 and 3 children also, the mean score of authoritative style in families with 2

Table 1. Comparison of the mean score of parenting style in three groups of families with 1, 2 and 3 and more children

\begin{tabular}{|c|c|c|c|c|c|c|}
\hline \multirow[b]{2}{*}{ Parenting style } & \multicolumn{3}{|c|}{ Number of children } & \multirow[b]{2}{*}{ df } & \multirow[b]{2}{*}{$\mathbf{F}$} & \multirow[b]{2}{*}{$P$ value } \\
\hline & $\begin{array}{c}1 \\
\text { Mean } \pm \text { SD }\end{array}$ & $\begin{array}{c}2 \\
\text { Mean } \pm \text { SD } \\
\end{array}$ & $\begin{array}{l}3 \text { and more } \\
\text { Mean } \pm \text { SD } \\
\end{array}$ & & & \\
\hline Permissive style & $19.97 \pm 5.13$ & $17.05 \pm 5.13$ & $16.03 \pm 3.54$ & 149 & 9.001 & $<0.001$ \\
\hline Authoritative style & $16.10 \pm 5.88$ & $19.56 \pm 4.70$ & $16.66 \pm 4.63$ & 148 & 8.278 & $<0.001$ \\
\hline Authoritarian style & $30.30 \pm 5.21$ & $30.13 \pm 5.99$ & $34.50 \pm 2.81$ & 149 & 6.874 & $<0.001$ \\
\hline
\end{tabular}

SD: Standard deviation, df: degree freedom 
Table 2. Comparison of the mean score of parenting style in housewives and employed mothers

\begin{tabular}{lccc}
\hline \multirow{2}{*}{ Parenting style } & \multicolumn{2}{c}{ Comparison between housewife and employed mothers } & \multirow{2}{*}{ P value } \\
\cline { 2 - 3 } & $\begin{array}{c}\text { Housewife } \\
\text { Mean } \pm \text { SD }^{*}\end{array}$ & $\begin{array}{c}\text { Employed } \\
\text { Mean } \pm \text { SD }\end{array}$ & \\
\hline Permissive style & $18.52 \pm 4.86$ & $17.17 \pm 5.74$ & 0.190 \\
Authoritative style & $17.92 \pm 5.09$ & $15.94 \pm 6.27$ & 0.050 \\
Authoritarian style & $30.71 \pm 5.43$ & $33.12 \pm 5.18$ & 0.150 \\
\hline
\end{tabular}

SD: Standard deviation

children was significantly more than families that have 1 and 3 children, and the mean score of authoritarian style in families with 3 and more children was significantly more than families that have 1 and 2 children $(\mathrm{P}<0.050)$, and there was a significant association between parenting style and the number of children (Table 1).

In investigation of the association between parenting styles and demographic characteristics, no significant association was observed but Pearson test showed that there was a significant adverse association between age and permissive parenting style $(\mathrm{P}<0.050, \mathrm{r}=-0.22)$. Comparison of the mean score of parenting style in housewives and employed mothers, with use from independent t-test; there was a significant difference between housewives and employed mothers in authoritative parenting style such that the mean score of authoritative parenting styles in housewives was significantly higher than it in employed mothers (Table 2).

\section{Discussion}

In the explanation of parenting styles, it should be mentioned that parents would be in one of the permissive, authoritative, and authoritarian groups. The authoritarian parents are very controlling, demanding and also very accountable and amendable. The permissive parents apply less of control and demand and much of accountability and acceptance. The authoritative parents are very demanding and controlling while their acceptance and accountability is low and they pay no attention to child's needs (16).

Baumrind found out that various parenting styles are different in two aspects: the first aspect is expectation and control and the other aspect is acceptance and compliance (13). Azad Moosavi and Jalali (17) have analyzed parents from these two aspects and found out that authoritarian parents have a high score in expectation and accountability. Authoritative parents had a high score in expectation also but a low score in accountability. Permissive parents had a high score in accountability and low score in expectation and inattentive parents had low score in expectation and accountability. It seems that among three studied parenting styles, the authoritarian style is closer to the responsible parenting which is recommended in our religious teachings. In the responsible parenting style, parents consider God's order on nurturing children. Therefore, responsible parenting which is according to the principles mentioned in Quran and Hadith may have positive outcomes. In responsible parenting style, parents believe that nurturing and guiding children are their duty and God oversees their performance, so they are accountable in dooms day and this guarantees 
their proper performance (5). Permissive and authoritative parents may not be successful in doing this. In this study, such parents were observed mostly in families with fewer children (1 or 2) and it seems that having more children makes parents more logical and it paves the way for nurturing children according to Islamic teachings.

According to the results, permissive parenting style in single child families, authoritative style in families with 2 children, and authoritarian parenting style in families with 3 and more children was significantly more common. It seems that having more children makes parents more logic and paves the way for nurturing children. The authoritarian parenting style is closer to the responsible parenting which is recommended in religious teaching and maybe permissive or authoritative parents will not successfully implement responsible parenting style. Unfortunately, the viewpoint of some parents about having only one child has led to the reduction in childbearing and this issue not only has some demographic consequences but it may lead to unsuccessfulness in proper nurturing of children in our country. Therefore, due to the importance, it is recommended to perform more studies on this issue and some proper educational program be planned for parents.

\section{Conflict of Interests}

The Authors have no conflict of interest.

\section{Acknowledgement}

We would like to thank research vicechancellery of Behbahan University of Medical Sciences that provides the financial resources for this study (The research project No. 9414)

\section{References}

1. Navabakhsh M, Fathi S. Parenting practices and children's social compatibility. Religious Study 2011; (22): 33-64.

2. Vahedi Sh, Lotfinia H, Yousefi Shahir N. The relationship between types of parenting and the emotional atmosphere of the family, and children's creativity in nursery schools of Tabriz. Woman and Study of Family 2009; 1(3): 107-21. [In Persian]

3. Hajigholami Yazdi A, Alagheband $\mathbf{M}$. Effectiveness of parental skills training on worry, anxiety and self-efficacy beliefs of single-child and multi-child parents. J Shahid Sadoughi Univ Med Sci 2013; 21(2): 136-47. [In Persian]

4. Madahi ME, Liyaghat R, Samadzadeh M, Moradi E. Examines the interaction adaptive behavior and parenting style. Journal of Health and Psychology 2011; 1(1): 43-62. [In Persian]

5. Shokouhi Yekta M, Parand A, Faghihi AN. A comparative study on child rearing styles. Journal of Islamic Education 2006; 2(3): 115-40. [In Persian]

6. Mirzabeigi $\mathrm{H}$. The Effectiveness of training how to bringing up children based on Iranian culture on parents' growing methods and children's achievements. Educational Developement of Jundishapur 2013; 4(1): 74-82. [In Persian]

7. Seifi Gandomani MY, Kalantari Meibodi S, Fath N. Typology of family parenting style (combination of maternal and paternal parenting styles) and its effect on male adolescents' anxiety and depression: A new approach to parenting. J Fundam Ment Health 2009; 11(43): 185-94. [In Persian]

8. Onder A, Gulay H. Reliability and validity of parenting styles and dimensions questionnaire. Procedia - Social and Behavioral Sciences 2009; 1(1): 508-14. 
9. Sardarpour Goodarzi Sh, Derakhshanpour F, Sadr S, Yasami MT. Comparison of behavioral disorders in single child vs. multiple children families. Iran $J$ Psychiatry Clin Psychol 2003; 9(1): 20-6. [In Persian]

10. Farnoodian $P, \quad$ Asadzadeh $H$, Ebrahimighavam S. Relationship between parenting style and perfectionism and selfregulation and comparison in students of single and multiple children families. Journal of Behavioral Sciences 2011; 5(16): 99-120. [In Persian]

11. Mobasheri M, Alidosti M, Sorshajani S, Khosravi F, Khalafian P, Jalilian M. Determination of the most important factors influencing the fertility patterns of single child and without child families in Shahr-ekord City in 2013. J Ilam Univ Med Sci 2013; 21(6): 63-70. [In Persian]

12. Boon HJ. Low- and high-achieving Australian secondary school students: Their parenting, motivations and academic achievement. Australian Psychologist 2007; 42(3): 212-25.
13. Faramarzi S, Taghipour Javan AA, Dehghani M, Moradi MR. The investigation and comparison between the attachment styles and mothers of child rearing in ordinal students and students with learning disorder. Jentashapir 2013; 4(3): 245-54.

14. Hatamnejad M, Asgharnejad Farid AA, Zahrakar K. Investigating the relationship between parenting style and social phobia Parents with high school teens social phobia. New Findings in Psychology 2013: 8(26): 53-63. [In Persian]

15. Zarei E. Relationship between parent childrearing practices and high risk behavior on basis of Cloninger's scale. J Shahid Sadoughi Univ Med Sci 2010; 18(3): 220-4. [In Persian]

16. Rezvankhah M. The relations among selfconcept, family structure. Studies in Education and Psychology 2009: 10(3): 177-96. [In Persian]

17. Azad Moosavi MMB, Jalali MR. Intergenerational transmission of family factors: Parenting styles, attachment styles and family climate. Journal of Family Research 2014; 10(1): 79-97. [In Persian] 